\title{
Analyzing the Role of Women in Italian Mafias: the Case of the Neapolitan Camorra
}

\author{
Felia Allum $^{1} \cdot$ Irene Marchi $^{1}$
}

Published online: 7 August 2018

(C) The Author(s) 2018

\begin{abstract}
Over the last twenty-five years, there has been a growing debate about the role of women in Italian Mafias. Using a qualitative approach, this article looks at the leadership roles of women in the Neapolitan Camorra covering the period 2000-2014. It argues that despite women's high-ranking positions within mafia clans, their professional development is best explained not as a sign of "female emancipation" of Italian or Camorra women but rather as functional exploitation by the clan when resources are limited in times of crisis. Thus, conceptualizing Camorra women as a "reserve army" can be a more useful analytical framework to explain the leadership positions of the women who come to occupy relevant positions in the traditionally men-dominated Camorra clans.
\end{abstract}

Keywords Italian mafias · The Neapolitan camorra · Mafia women · Female crime · Emancipation · Reserve Army

Hobbs and Antonopoulos once observed that "organized crime is a relatively difficult topic on which one can conduct research" $(2014,110)$. Analyzing women's involvement in crime is even more problematic because reliable material is very hard to collect. Qualitative observations of women's involvement have been considered biased because it is believed that these observations are subjective and often influenced by widespread traditional prejudices about women and their 'good nature' (see Dino 2007; Madeo 1997; Pizzini-Gambetta 2008). Italy and its different Italian mafias provide a good example of these issues.

Felia Allum

f.s.allum@bath.ac.uk

1 Department of Politics, Languages and International Studies, University of Bath, 1 West North, Claverton Down, Bath BA2 7AY, UK 
Until thirty years ago, the names and presence of women rarely appeared in judicial acts or newspaper articles about Italian mafia-type crimes ${ }^{1}$. Although at times it was acknowledged and even legally proven that women were aware and often involved with mafia groups, they were usually found "not guilty" (Fiandaca 1997; Zaccaria 2010) because they were only the wives, mothers or sisters of mafiosi. Women were not considered directly responsible for crimes; they were perceived by the judiciary, by the police but also by civil society in general (see Longrigg 1998), as unable to commit crimes or to have criminal intent because of their gender. As a result, men and women were brought to trial but faced differential systems of judgement and punishment. Until the early 1990s, it was "normal" and frequent for a woman involved in "mafia type" crimes to be acquitted.

The 1990s proved a turning point: A delicate political crisis (1992-1994), new antimafia laws - specifically Article 41-bis of the Italian penal code, introduced in 1982 - and changes in civil society all interacted in such a way as to allow women to appear in judicial investigations and newspaper articles. Statistics highlight this change: In 1990, there was only one woman in Italy accused of "mafia association" but by 1995, the number had risen to 89 (Ministero dell'Interno 1996). ${ }^{2}$ According to data from the Ministero dell'Interno between 1994 and 1995, the number of women prosecuted for possession of illegal narcotics or drug-trafficking rose from 37 to 422 (ibid) . Over the same period those for illegal usury went up from 119 to 421 (ibid).

Ingrascì (2007) identifies three specific reasons for this general increase at this particular time. First, the improved commitment of the Italian judiciary and law enforcement agencies to prosecute mafias, as well as the contribution of state witnesses, created a leadership vacuum as numerous bosses were sent to prison. Some women - at least those related to mafia bosses in prison or in hiding - had the opportunity to enter the chain of command and become influential players. These new judicial attitudes and the testimonies by state witnesses challenged the traditional stereotypes according to which "there are no women in the mafia" (Fiandaca 1997; Siebert 1996; Longrigg 1998). Second, the development of mafia activities prompted the search for a wider "workforce" as a matter of practical necessity. Third, some criminal organizations evolved over time, developing a more entrepreneurial dimension - the so-called "enterprise syndicate" (Block 1980) which required specific networking and economic skills. As women were statistically more prone to commit crimes that do not entail the use of violence, they found more space in these "new" sectors of criminal activity (see Zaccaria 2010; Zhang et al. 2007).

The role that women play in Italian mafias is determined by the history of the criminal groups to which they belong, the organizational structures of these groups, and their specific socioeconomic environments (Gribaudi 2010; Siebert 2010). The Sicilian Cosa Nostra and the Calabrian Ndrangheta have many similiarities: They are both originally rural organizations, they have a clear code of honor and internal rules and regulations based on traditional values and blood ties, and they are strictly hierarchical. One of their ultimate aims is profit but more importantly, so is power over a set territory, their members, the economy and the political process (see Siebert 1996; Fiandaca 2007). Membership is sanctioned by a formal ritual of admission into the group

\footnotetext{
${ }^{1}$ Article 41-bis of the Italian penal code defines the membership of a mafia type criminal association in the following terms: "When those belonging to the [mafia] association exploit the potential for intimidation which their membership ives them, and the compliance and omertà which membership entails and which lead tothe committing of crimes, the direct or indirect assumption of management or control of financial activities, concessions, permissions, enterprises and public services for the purpose of deriving profitor wrongful advantages for themselves or others" (Seindal 1998, 20).

2 In general, there are few statistics and data on Italian women in the mafias. The last document was published in 1996 (see Ministero dell' Interno 1996).
} 
and women are officially excluded from this ritual (Siebert 1996). The male-dominated hierarchy of power in this criminal landscape reflects the patriarchal mentality that is still widespread in southern Italy. This traditionally has not allowed women to participate in activities outside the domestic sphere. Indeed, the traditional gender imbalance remains stark and clear cut.

But in Campania, the Camorra's home territory, the picture changes. The Camorra is made up of loose affiliations of families, ${ }^{3}$ which associate or split according to their hegemonic aspirations and needs. There is no rigid structure, alliances are extremely flexible, and there is typically no affiliation ritual based purely on blood ties. The Camorra is originally an urban organization and is predominant in the most chaotic and deprived districts of the city of Naples where poverty, unemployment, and criminality remain high (see Behan 2002; Allum 2006). In the postwar period, criminal groups have appeared both in the city but also across the rural provinces and hinterland. In practice, it is true that Neapolitan women have always been active in the city's post war illegal economy, especially in the day-to-day running of extortion rackets and the selling of contraband cigarettes and loan sharking. They have also been present in the agriculture hinterlands and their inclusion in modern day Camorra criminal activities does not represent a significant change from the past (Longrigg 1998; Sales 2006).

Although there are women present and active in the other Italian mafias, more women have been able to access leadership roles in the contemporary Camorra. The urban origins of the Camorra have generally facilitated the entrée of women into many different types of illegal activities compared to mafias with more rural origins because of the constant and daily need for a criminal workforce. However, it is the more complex interaction of a variety of factors which may explain why these women have not found any formal impediment to entering the higher echelons of the Neapolitan organization. These include the Camorra's fragmented structure with no formal obligatory affiliation ritual, the Camorra's looser conception of family (less based on strict blood ties compared to other mafias), a demographic transition in the 1990s to a generation with less children ${ }^{4}$ (which meant that women-wives and mothersgained more strategic importance in the clan's business activities than if there were more male children), the introduction of new Antimafia legislation (especially, a state witness protection program in 1991, changes in the nature of the prison regime (Article 41-bis) for mafia bosses in 1992, introducing limited prison visits and women relatives now having "exclusive" access and new seizure and asset confiscation measures in 1992), the many arrests by the State of important Camorra leaders and the general evolution of the Camorra's business activities (particularly in the drugs sector) with the knock on effect of a need for more entrepreneurial activities. In the late 1990s, women such as Maria Licciardi of the Secondigliano Alliance or Erminia Giuliano of the Giuliano clan, appeared out in the open and became leaders. ${ }^{5}$

The aim of this article is not to compare the role of Camorra women with other Italian mafia women, but to revisit their role by using new material - namely ethnographic interviews and trial and police documents - to establish their life stories, clan activities and influence to better understand their emerging leadership roles today. In the following section, we present the study's methodology. Next, we review the existing Italian and Anglo-Saxon literature on the role of

\footnotetext{
${ }^{3}$ In this article, we use the terms clan, criminal groups, Camorra families and mafias interchange by to refer to small criminal camorra groups often connected by blood ties and kinship.

${ }^{4}$ There are clearly exceptions: for example, Paolo Di Lauro, an important leader during the 1990-2000s had 8 male children, which may explain why women were hardly visible in the clan. See Brancaccio (2017) for good overview for Camorra families.

${ }^{5}$ There had been other women involved in Camorra activities such as the sister of Raffaele Cutolo or the mothers of various bosses but they were always seen as support systems rather than taking up leadership roles.
} 
women in Italian mafias. Finally, we elaborate a new approach and apply it to empirical case studies before concluding why women have been able to achieve leadership roles in the Camorra.

\section{Methods}

The research presented in this article is the result of a long journey in which we tried to understand the role and presence of women in the Neapolitan Camorra. It is part of a larger study on the Neapolitan Camorra in Naples and abroad. This article is the product of a collaboration between the two authors and part of an ongoing study. Some of the extensive fieldwork and interviews relating to Camorra women are presented here.

To try and counter some of the potential problems - such as access to concrete data-we adopted a qualitative mixed methods approach, combining ethnographic interviews with the analysis of new judicial, police and newspaper articles. This article is based on the triangulation of data. By triangulating data and using mixed-methods the intrinsic biases linked to single-method studies are avoided (Arsovska 2015, 10).

Regular fieldwork in Naples over the last 20 years has enabled the authors to collect a vast amount of varied information to re-construct the life stories, activities, and the roles of Camorra women. The first author has spent approximately a month each year in Naples since 1997. Using judicial material and newspaper articles, a general framework of the Camorra clan and women's roles in it was put together through life stories, relationships, activities, and clan alliances. In order to add detail to this framework, ethnographic interviews were then conducted and discussions with police officers and judges took place in order produce an overview and map out the way women behaved in the clan (recruitment, activities, role).

It was important to think about what was the best way to access and analyze this kind of material because, as Hobbs and Antonopoulos, have pointed out, "The researcher who wants to access active organized criminals directly must recognize that there are seldom any obvious benefits for participants - distributing questionnaires to them or asking them to sign consent forms are less than well-thought approaches" $(2014,96)$. In other words, other more flexible and practical methods must be adopted when thinking about how to access information about criminals, their lives and activities.

Analyzing the role of women in Italian mafias is not a straightforward task because mafias are complex criminal organizations that are difficult to study. Firsthand encounters, participant observations and direct experiences are complicated to document when it comes to studying any organization involved in illicit activities. Although an ethnographic approach would probably be the best way to get close to such a complex social phenomenon (as was the case with William Foote Whyte [1943] or Jason Pine 2012) this is not always possible. As our specific interest was the involvement of Neapolitan women in Camorra activities and decisions, access was a particular problem, given their involvement in criminal activities, as well as how to engage with them to understand their importance and role.

Because direct participant observation was not possible, it was more feasible to document the role of Camorra women through interviews with them and with those whom they came into contact (for example, former mafia members, judges, police officers, and journalists) and by reading what people said about them. Interviews allowed us to gather first-hand information, even if "the interview can create as many problems as it solves" because of access, sample, 
quality, relevance (Rawlinson 2000, 357). However, all things considered, ethnographic interviews were seen as one of the most appropriate academic tools for this study.

Ethnographic interviews were undertaken in order "to get people to talk about what they know" (Spradley 2016, 9) because ethnography "is the work of describing a culture. The essential core of this activity aims to understand another way of life from the native point of view" ibid, (3). This interview approach allowed for the collection of a lot of rich data, in particular from former Camorra women themselves, which not only allowed the authors to engage directly with them but also tease out details and information not necessarily present in standard judicial and police reports. It is important to note that their narrative and stories are not the truth but a truth, one among many.

Various types of interviews were conducted between 1997 and 2017: 1) casual semistructured and in-depth interviews with police officers ${ }^{6}$; (2) structured interviews with public prosecutors (from the Naples District Antimafia Directorate), who had handled cases related to Camorra women and (3) semi-structured in-depth interviews with former criminals turned state witnesses. ${ }^{7}$ Since 1997, the authors have interviewed and talked with 11 State witnesses who are former camorristi, ${ }^{8}$ over 20 Neapolitan anti-mafia public prosecutors, over 15 police officers and over 8 local journalists. This interview data has contributed to existing knowledge by giving a voice to some of the protagonists, by allowing a reconstruction of life stories and events, and by providing an insider's perspective, all of which is missing from the mainstream academic literature. In terms of validation, the authors triangulated the interpretation presented in the interview transcripts - dates, facts, events (see Perakyla, 1997) in order to establish facts, events and the women's role in the clan.

A case study approach was adopted because it is 'particularly useful when there is a need to obtain an in-depth appreciation of an issue, an event or a phenomenon of interest, in its natural real-life context' (Crowe et al. 2011, 100); in other words, women's leadership roles in the Camorra. Moreover, a qualitative case study approach "provides tools for researchers to study complex phenomena within their contexts;" an approach that "facilitates [the] exploration of a phenomenon within its context using a variety of data sources. This ensures that the issue is not explored through one lens, but rather a variety of lenses which allows for multiple facets of the phenomenon to be revealed and understood" (Baxter and Jack 2008, 544). By using a case study approach, we prefer going into depth into each unit of study (in other words, examining the detail of the lives of Camorra women) rather than studying many women's lives (but remaining superficial). Here, depth is preferred over breath because it is believed that such an approach may highlight some important elements so far ignored.

Through a careful analysis of the Camorra clan leadership roles in the 160 clans in Campania during the late 1990s until the early 2000s (see Allum 2016, 4), we see that women took on more active roles in their criminal group, especially when it was under police investigation or in crisis, with male leaders being sent to prison or forced to go on the run. The seven clans from the city and the province were selected because they were more recent cases, there was an abundance of material available about them, and there was the possibility

\footnotetext{
${ }^{6}$ From the three different Italian police forces: Guardia di Finanza, Polizia di Stato and Carabinieri.

${ }^{7}$ More specifically, four women state witnesses were interviewed between 2010 and 2016 to get firsthand accounts of their visions and experiences.

${ }^{8}$ For ethical reasons, their names are not listed here. The first author interviewed a first group in the late 1990s and started interviewing again from 2010. Four of these interviewees were women.
} 
of interviewing some of the protagonists in four of the cases. ${ }^{9}$ All the women studied have been arrested, while some of them are still in prison under the 41-bis penitentiary regime. ${ }^{10}$ What is revealing is the similar trends and patterns that appear from all these women's life stories.

For this article, the interviews and life stories of three Camorra women who became state witnesses were analyzed in greater detail: AC from the Bidognetti clan (Casal di Principe), RA from the Amato clan (Santa Maria di Capua Vetere), AM from the Danese subgroup (Ercolano). ${ }^{11}$ It is important to note that although there may be more women who have become state witnesses in the Camorra compared to the other Italian mafias (20 to 11 women in Cosa Nostra and 8 women in Ndrangheta), this is still a very low figure when compared with their male counterparts (539 male Camorra state witnesses compared to 20 female ones in June 2015) (see the Senato della Repubblica 2015, 12). In this respect, we were very fortunate to have access to them (four out of 20 women Camorra state witnesses in 2015). It is hoped that their voices may contribute to a better understanding of Camorra women in Italian Mafias.

\section{Analyzing the Role of Women in the Camorra}

For many years, the dominant school of thought was based on the notion of "female emancipation." One of the first authors who connected female crime rates to emancipation was Freda Adler (1975). She argued that female criminality was the "dark side of feminism," one of the side effects of women's emancipation and masculinization in society that provided women with greater opportunities in everyday life, both in its legal and illegal dimensions. Her "liberation theory" was disproved later by statistics but in developing this interpretation of the concept of "criminal emancipation," she established that women's position in broader society shaped the role and incidence of women in the criminal world (Beare 2010). Her ideas were strongly criticized by both feminists and anti-feminists but many authors have acknowledged her insight and built on her work as a starting point for further analysis.

Contemporary Italian scholars broadly agree that the notion of female emancipation does not adequately explain the role of women involved in mafias. Siebert and Ingrasci- - analyzing Cosa Nostra and "Ndrangheta - employ concepts such as "ambiguous emancipation" (Siebert 2007, 37-43), "affirmation of a pseudo-subject" (34-36) and "pseudo-emancipation" (Ingrasci 2007, 84-91) to emphasize the paradoxical condition of women in the mafias. Women do play de facto key roles in the clan as exceptional upholders of traditions and values in the domestic context, but also, and increasingly, as active participants in illicit activities. Both authors recognize that women can be excluded and banned from an

\footnotetext{
9 These were the De Luca Bossa clan (Ponticelli), the Buttone clan (Marcinese), the Bidogneti clan (Casal di Principe), te Giuliano clan (Forcella), the Amato clan (Santa Maria Capua Vetere), the Danese-Ascione clan (Ercolano), La Torre clan (Mondragone). There did not appear to be a difference between city clans or province clans in terms of whether women were allowed to access leadership roles. It was more related perhaps to the situation of the male leadership.

${ }^{10}$ They were Teresa De Luca Bossa (De Luca Bossa clan), Maria Buttone, Concetta Zarrillo (Buttone clan), Esterina Pagano (Bidognetti clan), Marianna Giuliano (Giuliano clan) while others have been released or have become state witnesses such as Anna Carrino (Bidognetti clan), Rosa Amato and Emilia Maio (Amato clan), Anna Maria Giarra (La Torre clan).

${ }^{11}$ We decided to use initials rather than their names, but they are all recognizable as their stories have been published elsewhere and are well known. All agreed to being interviewed and for the material to be used for academic purposes.
} 
organization by formal rules which openly prevents them from being formally admitted while at the same time, they can also be recognized as effective members of this very group (Ingrascì 2007; Siebert 2007, 2010).

For the Camorra, the picture is even more complicated. The label "emancipation" is used by Gribaudi (2010) and Zaccaria (2010) with some reluctance. They deem it potentially misleading, producing an erroneous understanding of the role of Camorra women. They accept its use to describe the level of independence Camorra women have from men because they have gradually gained autonomous positions in their private lives (often separated, divorced or mistresses of prominent camorristi) and in the clan's activities (Gribaudi 2010; Zaccaria 2010; see Gribaudi and Marmo 2010). Zaccaria (2010) speaks of a "feminization" of the processes and structures, but this qualitative assessment should not be confused with the processes of deep emancipation or innovation: Women have always been present and involved in the illegal economy of Naples and, in recent times they have reinterpreted their traditional positions in a more "modern" way, adapting to contemporary societal changes (Gribaudi 2010).

Another useful concept for understanding the acquisition of power by women in Italian mafias is that of "temporary delegation of power" (Principato and Dino 1997, 68-69). This concept describes how, when the leader, the capoclan, is absent because he is incarcerated or on the run, his wife, sister, mother, or daughter is temporarily allowed to be in charge of the clan and its activities, giving orders and managing businesses on his behalf (Manna 2005; Siebert 2007). The introduction of the maximum-security prison regime, "hard prison regime" (Article 41-bis) also increased the role of women in mafias as they became the only permitted visitors for 41-bis inmates and as a consequence, the privileged channel of communication between a boss and his clan. In this way, they, acquired a central role in the group as they became the guardians of essential information between boss and members - in effect, the gobetweens and the delegated head of the clan (Manna 2005).

A distinctive feature of the signore della Camorra is their marked sentimental independence and vivacity, when compared to their Sicilian or Calabrian counterparts. Many of them have a background of troubled marriages, betrayals, divorces and separations from their husbands (Gribaudi 2010). This is at odds with the traditional image of the submissive and deferential wife, typical of the patriarchal mentality of other mafia environments such as Cosa Nostra or the "Ndrangheta. The idea of Camorra women as "unconventional" mafia women is further strengthened by the masculine manners and language that these women frequently deploy: acting and talking like men, intimidating enemies and even resorting to violence to solve arguments (Gribaudi 2010) as was the case of GH, who behaved like a man because she transported arms for the clan from one place to another (Guardia di Finanza 2005, 11). Furthermore, the existence in the Camorra of women with a certain degree of decisional power who control autonomously entire sectors of the clan's illicit business has been a further incentive for academics to opt for the emancipation paradigm in order to explain such a high female incidence in the system, not only in the private but now also in the professional spheres.

Despite the introduction of tailored versions of the concept of emancipation that better suit Camorra women - such as "pseudo-emancipation" or "ambiguous emancipation" (Ingrascì 2007; Siebert 2007, 2010) - it is the very use of the word emancipation which generates a degree of confusion. If female emancipation means - at least theoretically - total freedom from men's control and from man-centered schemes in all aspects of life (both private and public), how is it possible to talk about "gender parity" in an environment where a woman cannot even aspire to build her own career, albeit a criminal one, if not entrusted with this role by men? How can a woman be labelled "emancipated" if, in order to be fully accepted by the clan, she 
has to act and talk like a man? The question of how to analyze these women has become extremely controversial and the debate is on-going: Are Camorra women truly emancipated? Indeed, despite their apparent sentimental independence and professional ascent, a more attentive look at the processes of female involvement in the Camorra reveals some elements that point in the opposite direction, unveiling a deeply rooted male centered and male dominated mentality which seems to persist at the heart of the whole criminal system.

More recently, other approaches have focused specifically on what women provide the clan, in contrast to men. In particular, the "gendered market" perspective to organized crime (Zhang et al. 2007) identifies a gender-based division of labour within the criminal group. This approach asserts that, overall, the more violent a task is, the less likely it is that a woman will be involved. It is based on the belief that the tendency of women is to avoid violent situations and physical risks (Campbell et al. 2001; Savona and Natoli 2007). ${ }^{12}$ Zhang et al. (2007) argue that the expansion of more economic-oriented and less violent business activities in illicit markets is one of the main reasons for the increased involvement of women in organized crime. $^{13}$

Historically, women in the Camorra have been most active in the sectors of extortion, usury, gambling, drugs and firearms trafficking but this does not mean that the "dirty job" (i.e. the use of violence which often accompanies these practices), is totally delegated to the men. The neat division of role or gender segregation proposed by the "gendered market" approach does not exist in the Camorra. In recent years, Camorra women have directly engaged in bloody feuds and vendettas [revenge killings] against their criminal rivals, enemies and those that betrayed their clan. They act and behave just like men, intimidating enemies and dominating their clans by using aggressive words and violent threats, without hesitating to resort to the use of weapons or murder (Gribaudi 2010). Anna Terracciano-also known as o' masculone (big macho) - is one such example: Using her masculine attitude and aggressive temperament, she was not only involved in the clan's affairs but was also a member of a hit squad that travelled the city constantly armed (Zaccaria 2010).

Camorra women have also ordered or personally carried out brutal murders on behalf of their clan. For example, Maria Licciardi of the Licciardi clan, was described in an interview by a former camorrista as "very evil" for the acts that she ordered and the ultimate leader of the clan because one of her brothers was on the run, another had died and the other was in prison. "Even though she was a woman" she had a leadership role (Tribunale di Napoli 2003, 37).

These developments contradict Pizzini-Gambetta (2009) when she argues that "As long as women need to delegate violence I doubt that matriarchy will replace patriarchy in mafia or camorra groups since violence and command cannot be parted in that industry' (270-271). According to her, Camorra women assume "their role thanks to their exclusive relationship with men involved with the organization" and remain subordinates because "violence cannot be delegated permanently in the Camora." Again, the stereotypes according to which women are more pacific and less violent than men, only participating in financial activities, seem not to apply to the modern Camorra.

Looking specifically at women related to Camorra bosses (wives, sisters, mothers, daughters, or even mistresses) who acquire decision-making power within a clan, some questions

\footnotetext{
${ }^{12}$ Campbell et al. (2001) employ women's greater fear of violence as a key to explain the lower female involvement in crime compared to men. According to such a theory, the efforts made by women to avoid physical risks and protect the integrity of their body are connected to an unconscious maternal concern.

${ }^{13}$ The study of Zhang et al. (2007) namely focused on Chinese human-smuggling networks.
} 
arise: How do they come to power? What conditions must they fufill? Are there necessary conditions that they must meet? Or can any woman come to positions of power? These are some of the questions that this article addresses; in particular, it seeks to provide a new theoretical lens based on new material for the understanding of the role of women in the leadership of the Camorra today.

\section{The "Female Reserve Army" Approach}

The underlying idea of our approach is that Camorra women's entrée into leadership roles is not linked to the concept of female emancipation but rather to the idea of exploitation of available resources and skills. In the Camorra, the space left for women remains limited and whatever degree of authority a woman can achieve does not imply authentic progress in her criminal career but rather reflects the mere result of the interplay of particular situational factors and familial conditions that have made her "call to arms" necessary and possible. Recruiting women to top jobs, even influential ones, can be seen as a mere instrument for filling gaps in the management of the clan during difficult times, when it is under attack from law enforcement agencies or in conflict with rival families; the survival of the clan is constantly under threat, especially when it is deprived of its leaders. In fact, a clan in such conditions risks complete eradication by rivals and the help of women at this point becomes inevitable. They become the only reliable resource available to the clan. A criminal family lacking experienced personnel needs to restore order quickly to its membership to maintain hegemony over its territory before other clans undermine it. And, given the lack of adequate male figures, women acquire an exceptional importance, being the last resort for the clan's survival. In these moments of crisis, they can often adequately substitute for men in leadership roles, showing brilliant organizational skills both in terms of financial management and human resource administration. This extraordinary "crisis management system" becomes essential for the regeneration of the clan and the reorganisation of its ranks.

Our approach is based upon the Marxist concepts of labor, unemployment and capitalism (Marx 1867; Bruegel 1979). According to Marx, in a capitalist society, the unemployed and underemployed represent the "reserve army of labor" and are a "hidden" but essential element of the capitalist equation. In fact, by creating a certain degree of job insecurity, the mere existence of the unemployed and unemployment contributes to keeping wages low and to motivating employees to work more and more efficiently. In times of economic crisis, the pool of reserve workers, which provides the human resources required for capital accumulation, shrinks; conversely, as capital increases, the reserve army of the unemployed grows again (Marx 1867; Bruegel 1979).

Reserves do not make decisions as to when they do or do not enter active service; rather, it is the broader system with its dynamics and hierarchies that determines when and how to deploy them. Just as the unemployed are considered the reserve pool of workers, women in the Camorra can be seen as the "reserve army" of the clan in times of crisis: When key members are in prison, or in hiding, and no other valid male successor is available. According to Marx, in normal conditions capital will always try to employ the fewest reserve workers as possible. The same can be said for the Camorra. It will always be naturally self-restraining in drawing or calling upon its female reservoir. As a result, the Neapolitan organized crime scene is today still largely men-dominated and women remain, by and large, latent support to the criminal and biological family. 


\section{Camorra Women}

In order to show the explanatory value of this approach, it will now be applied to three formerCamorra women who have been interviewed for this study. ${ }^{14}$ These female protagonists had all become important leaders or leading figures in their clan. In these case studies, we focus on how they were "recruited" and how they were able to access leadership roles.

\section{The Bidognetti Clan, Casal di Principe}

The Casalesi Confederation (known as 'I Casalesi') was an extended conglomerate of clans operating in the area of Casal di Principe (Caserta province) and its neighbooring districts. It was not as fragmented and disjointed as the city Camorra clans and its hierarchical structure mirrored that of the Sicilian mafia, with which it has often been linked. ${ }^{15}$ At the top of the pyramid of power there were a few, powerful bosses who controlled the whole organization collectively but who managed their own clans independently. The first prominent boss of the Caserta Camorra was Antonio Bardellino, active during the 1980s. During the 1990s to 2000s, the senior leadership was made up of a small number of intelligent and violent bosses. Francesco Schiavone known as Sandokan and Francesco Bidognetti known as Cicciotto 'e Mezzanotte were two of the most influential figures, the leaders - respectively - of the Schiavone and the Bidognetti clans, the two most important families that formed I Casalesi (Di Fiore 2008).

AC, the partner of Bidognetti for over twenty years and the mother of three of his children, was arrested in 2007 and accused of mafia association. In November 2007, she became a state witness and collaborated with the state, abandoning her life in a Camorra family and clan. AC was not born into a Camorra family. AC's was born into a family of five children. Her mother was a nurse and her father a shop assistant; they were both from Naples, but her father soon left the family. She explained that she was born into "an ordinary family... a family that didn't have anything to do with the Camorra. They didn't know anything." Her childhood was sometimes "stormy" but bought up by the nuns, she had traditional catholic values: "Love your fellow beings, look after your family, have children, look after them, stay close to them, go to church every Sunday." Even today as a state witness, she revendicates her religion, which she held dearly, even as the "boss's woman." She says that "despite being with a mafioso, a camorrista, [...] it didn't make me change my faith."

Rather than being actively recruited into the Camorra, at the age of 13, she met and fell in love with Francesco Bidognetti, an emerging Camorra boss; she first became his lover and then the mother of his children and companion for over 20 years. Within a few years she had moved from the Vomero district in Naples to live with his mother in Casal di Principe while he continued to live officially with his wife. At the age of 17 , she had given birth to their first child, a girl. In 1988, after his first wife had died, she became his official partner and even looked after the children from his first marriage. In this way, she became subsumed into his blood family but in real terms this also meant his criminal family, his Camorra family where in due course she would become useful to the clan. Here we can see how "the emotional value of

\footnotetext{
${ }^{14}$ All interviewees consented to being interviewed and were explained how they would be used. We thank them for this. All translations are the authors'.

${ }^{15}$ The original boss of the Casalese group was Antonio Bardellino, who during the 1970s was co-opted into the Sicilian Mafia.
} 
the family was extended into a strategic and functional one...family relationships were now exploited not only to provide protection for members on the run but also to make money and to recycle illegal earnings" (Allum 2007, 333). She was still young, and for the first few years she was under the control of the boss's mother, who was very present and controlling: "I was always home. I would never go out. If I went out, I would go out with my mother-in-law... She knew everything, because she was his mother." Once her mother-in-law had died, she had more space and became in her own words "the boss's woman."

On the one hand, AC says that "this situation changed my lifestyle, as we had more opportunities to have money in our pockets. If you wanted to buy many things, you could do that. You had respect, because you were the boss' wife." Indeed, being the boss's woman brought many privileges: "It's true that nobody could touch you." According to AC, everyone respected her: "Respect, meaning that if someone came up to you, they would say 'Be careful, because she is Bidognetti's wife." On the other hand AC told us: "You were not free to do what you wanted. You were given rules. You were deprived of your own life...so many things...There are people who say that the wife is always the wife. They don't need to have relations with other people." She reflects, "I denied myself everything for [my husband]."

While the boss was free to manage his criminal family business in Casal di Principe, AC underlines how women were kept out of Camorra activities and decision making: "They don't want women to participate." She goes on to say: "They totally respect women and, therefore, women have to step aside and can't take part [in criminal activities which they consider to be a male only domain]." This may be because on the surface the Casalesi clan are closer to the Sicilian mafia in mentality than city Camorra clans. She then reflects upon the role of mothers: "The woman must be mother to the children, she must look after the house, she must cook, she must do what they say, when they say, what you can do, what you can't do." Mothers are sacred: "You are the children's mother. Your role is to be a mother to the children and you can only understand things up to a certain point." In particular, "they don't allow you into meetings. Or if you are talking about something, they stop quickly...Maybe you are in the kitchen feeding the kids, they don't stop in the kitchen to talk. They go to another room, because you are not to listen. You are not to listen to what they are saying." Women were therefore only useful for smaller, more practical jobs that were often beyond suspicion. She explains that "you go, because you're a woman. It's better if you are woman. I won't send a man to that person."

While Bidognetti was out of prison, AC accepted her role as a passive one because "I can tell you that my partner, from the moment he got [out of prison] to the time he was arrested, he has always kept me out of it. Always. Always. He would always tell me: 'I am the one who should go to jail. My kids should go to jail, if they have to go to jail, but not you, because you are the mother of my children. You only have to raise my kids. ${ }^{16}$ You shouldn't know anything..." AC had difficulty when explaining her exact involvement in the clan. The discussion was delicate, often awkward because accepting her "criminal" role was not straightforward. After reflection, she accepted her involvement of the clan in Casal di Principe as taking her husband's wage and distributing their member's salaries: "No, I don't feel involved in this thing...I'm passive, yes...However, even though I was in that situation [I took part by doing what they asked me to], I couldn't make decisions, because I was nobody to make decisions... They didn't even authorize me to make decisions....I was at home, yes, that's true, but I lived the situation in a passive way... I was passive in that moment. [...] No.

${ }^{16}$ And, his children would do anything for their father, as she says "they would die for their father." 
No. It was passive. I was home and I took the wages. They would bring the wages to me [to distribute]". She clearly states that she did not take decisions.

When her partner went to prison under the 41-bis regime, he continued to be in charge: "Well, he gives the orders. He does. You don't think that because one goes to jail, he won't give orders anymore?" The implication of this was that the immediate family and the lawyer were the only ones to have access to the boss and his instructions. AC's role changed and became more vital than ever. She argued that it is not the role of the wife that becomes important but that of the entire family and those who have access to the boss. She stressed the role of the family:

When they [the boss] need [something], they always talk with the person who's closest to them. They never talk with their members, because their members can betray them, but not their wife, not their kids, not their brother, not their sister and not even their mother can betray them. They need the family, not their wife. The wife per se... that role is of the family. If they need their members, they trust their members to a certain point, because their members do the extortions but the person in charge is always the person in jail. And the messages are delivered outside [prison]... by my brother in law, I would have done it, my mother-in-law would have done it, the wife would have have done it.

She explained her perplexities about her role as messenger and being the representative of the boss: "When he was in jail, if today he asked me to bring money to you, tomorrow he could have asked something else, bigger than me. And I wouldn't have been able to face that...I wouldn't have been capable of ... not at all". Here, the notion of "reserve army" is useful. AC had continuous direct access to Bidognetti while he was out of prison. By sharing his life, she was able to interact with the clan members, giving her insights which she would soon make use of. Once the boss was arrested and the clan in disarray, she took on a more active role, becoming his de facto representative on the outside, and relaying messages to his members (Tribunale di Napoli 2016), even if she has difficulty in verbalising this.

\section{The Amato Clan, Santa Maria di Capua Vetere}

According to the judiciary, RA was the daughter of a local boss, and his right hand woman. In particular, she was in charge of her father's accounts (she managed the slot machine sector, was involved in loan sharking, and took care of all the financial aspects of the business).

RA, "Rossana," was born into a a family of fishmongers in Santa Maria Capua Vetere (Caserta Province), who owned their own business and worked hard to make a living. She was brought up to respect traditional values such as the importance of family. Her parents separated when she was betweeen 10 and 11 years old. Her brother (who was a year younger) went to live with her father, while she remained with her mother. She describes her father as a "father boss" ("padre padrone"), an authoritarian man with set rules who was a "womanizer." $\mathrm{He}$ already had a certain reputation at that time but was not yet a boss in his own right.

Things dramatically changed for her family in 1999 when her brother, 20 years old, was murdered. C. was stabbed to death at a disco while defending a girlfriend from the attention of young members of the powerful Casalesi Confederation: "It was the moment when our lives changed. Decisions were made." Her father's reaction was to initiate a vendetta to avenge his son's murder. He would say, "I am going to Casale, I will put on an explosive belt and I will blow myself up but they all need to 
die." But instead of avenging his son's murder in person, ${ }^{17}$ he became close to his cousin, the boss of the Belforte clan of the Marcianise region, and his criminal reputation began to grow. So much so, in fact, that he established his own clan. The Amato clan was small, consisting of a handful of men, all driven by hatred for the Casalese clan. Its main activity was the hiring out of slot machines. ${ }^{18}$

Initially, RA went to the university of Santa Maria Capua Vetere to study law, ${ }^{19}$ but as her father's clan took off, and in particular the slot machine business, she quit to assume responsibility for this part of her father's operations. The Amato clan soon developed into a traditional Camorra clan, becoming involved in extortion and violence. ${ }^{20}$ She explains that she was really the only one of the clan members qualified to manage the rigged slot machines business, and so "she could no longer study [in those conditions]." Her father recruited young men and established a violent clan. RA was kept away from the violence and focused on financial matters, but nevertheless her close contact and daily conversations with her father helped her to develop her skills. Moreover, she got lucky following several amendments to the law that favored the slot machine sector. Previously illegal, they suddenly became legitimate, and this meant that "the fact that they became legal, all bars started to have slot machines. Bars and even tobacconists had a slot machine for example. It was not like this before. So, having to distribute and manage many slot machines meant a lot of profit." The clan imposed them on businesses, rigging them in such a way that they made money for them.

RA was allowed to take on this important role because the other members were somewhat incompetent. She did not see herself as a member of a violent clan because "I did not feel like I was participating in the violence, so I had a clear conscience." "But" as her father pointed out during a conversation, "you liked the big car, you liked to drive around in a car that costs 50,000 euros, you liked going to the beach, 365 days a year. In the end I became like them, I did not use violence because I was a woman... but if I had not been there to keep the money coming in, they would not have been there either." She argues, "Without money, you (your clan) do not develop, therefore women contribute more than men...It is not because you are violent that you are good. I think that you need other things to be good, in the sense that without money, there is no Camorra, there is no clan, there is nothing." She did not identify with the violence of her clan because, as she explains, "I did not think in that (Camorra) way because as I said, the company was legal. I did not think about the extortions and violence. I liked the lifestyle because I lived well."

Later on, after her father was arrested, she became even more important, and took on a leadership and managerial role, distributing salaries together with her father's partner. The judicial investigation noted that "the daughter, in the absence of her father, managed the funds of the clan, "adding, "there is evidence that the Amato clan is still operative even after the arrest of SA and other members, and it is clear that the leader manages the criminal group even from prison through ME and RA" (Tribunale di Napoli 2011, 51).

She reflects upon the role of women in the Camorra and suggests that women are key to the clan's continuation: "From my perspective the state is managing to cut off the legs of the mafiosi. Mafia bosses are in prison but the Camorra still exists...because there are the wives." She also notes how sexist society is, in not noticing the involvement of women: "The

\footnotetext{
${ }^{17}$ Someone was murdered for the death of Carlo but it was not the murderer. It was an attempt to introduce an element of peace to the situation.

${ }^{18} \mathrm{C}$. was involved in this activity before his murder. He also sold drugs.

${ }^{19}$ She sat for five exams.

${ }^{20}$ The clan was accused of two murders. See http://www.comunicocaserta.com/website/?p=23833
} 
camorristi think that the investigators wouldn't get there, won't get to the wife. They are not separate. Whatever the husband does implicates the wife, and she can become a front name. It all seems absurd to me, for example, if the husband engages in [Camorra activity) and the wife does not work, the money comes from the mafia."

She firmly believes that women are the future leaders of the Camorra: "If a husband gives the order to burn a car, I say to so and so to go and burn a car, if the women hadn't helped the clan, the car would not have been burnt." Moreover, she argues that the state is also playing its part in unintentionally influencing women's roles in the Camorra, "as the state is making women pay, I have seen some quite high sentences, women will become emancipated like the men, in the sense that they too will give orders, like in the world of work. In the world of work, women have become emancipated...There will be a woman who will give orders (one day)." She said this is because women are "colder, more calculating."

\section{The Danese Group, the Ascione Clan, Ercolano}

AM was the wife of a young boss of Ercolano. After he was sent to prison in 2010, she took over the reins of his clan and became its leader. She managed the salaries of five members and another two who were in prison, as well as overseeing extortions, usury and a drugs piazza. AM is another example of a young woman from "an ordinary, normal family," who became attracted to a "bad boy," "attracted to that which was different," someone who was respected by the local community. She met her future husband at school at the age of eleven and soon went to live with him. They had a daughter while her husband's criminal career within the Ascione-Papele clan took off. With his men, her husband managed a local drugs piazza in Ercolano, ${ }^{21}$ and she helped him in his criminal activities (drug dealing, extortion rackets, usury).

One Camorra state witness describes her thus: "She is not a simple housewife but actively participates in the clan's activities, so much so that she has given orders or instructions concerning the beating of people who did not show her respect" (Tribunale di Napoli 2007, 10). In this way, she was fully involved and knew all about his illicit activities. She collaborated and cooperated with her husband and his men. By virtue of being his wife, she was able to receive specialized training in the reserve army.

This was their "golden period," which lasted from 2007 to 2010. But the law soon caught up with them. "The boss was arrested in 2010, and his clan was lost without him. At the age of 26, AM stepped into his shoes and took control of the clan" (Tribunale di Napoli 2007, 11). The judiciary noted that AM "appears to have different characteristics. Her leadership role appears to be independent from that of her husband; she manages to impose herself on clan members in such a way that she is considered (according to a number of state witnesses) to be the leader/regent of the clan (Direzione Nazionale Antimafia [DNA] 2014, 94). Moreover, the arrest warrant stated that although "she received orders and instructions from her imprisoned husband," she "also decided and participated in the clan's criminal activities" (Tribunale di Napoli 2007, 10).

Thus, although she filled the leadership vacuum, she appears to be still fundamentally linked to her husband, even though she demonstrated a certain criminal flair. She learned from him by being at his side when he started out, and was with him every step of the way. As she explains, "I knew everything." So, when he was arrested, "I put myself forward. He [her

$\overline{{ }^{21} \text { A group of five men aged } 20-25}$. 
husband] made it clear to everyone that I was the only one he trusted. He did not ask me [to put myself forward]." In this way, she looked after every aspect of the clan until she too was arrested: from dealing with and paying lawyers, managing the drugs piazza, overseeing the extortion rackets and looking after the usury activities. She was respected only because of her husband, even though she was very competent in her own right.

Whereas the judiciary suggested that she went beyond her husband's power and became a leader in her own right, we cannot be so sure, because the moment she became emotionally involved with another man while her husband was in prison, the clan and its members turned against her. They used violence to punish her and physically expel her from the territory. Once she was disloyal to her husband, she lost her control over the clan, and was left with no criminal credibility or reputation. If she had been a true leader in her own right, she would have been able to resolve this small incident and would not have found herself marginalized and vulnerable.

She reflected upon the role of Camorra women and believes that one day women will be able to take the lead, even if for the moment they are still in their men's shadows. She explains, "What women want, they obtain...women are more intelligent and look at things in the long term." But, "more than anything, it is a question of mentality...they are more capable."

\section{Camorra Women as "A Reserve Army"}

Through our case studies, we conceptualize the main characteristics and responsibilities of the female "reserve army" of the Camorra, using the example of the US Reserve Army. The United States army consists of an active army and an army reserve (USAR) (US Army 2013). ${ }^{22}$ The USAR is a reserve pool of soldiers that are expected to act in specific situations to aid and support the US active army "by providing a flexible, well-trained, complementary force that can expand and contract to meet the specific needs and challenges of each new mission" (US Army 2013). In other words, when the armed forces find themselves in a crisis situation, without sufficient human and organizational resources for the successful implementation of their objective, the reserve army is called in. The same logic is used with regard to women in the Camorra. Camorra women correspond to reserve soldiers - more precisely, a "reserve camorrista" - who acquire power in times of emergency when the boss is absent and the ranks are particularly destabilized. They represent "a crisis team," to be used in an emergency situation until competent men can take up the reins once more.

USAR soldiers are as devoted and motivated as their active counterparts. They are, in effect, "soldiers on standby" who have undergone the appropriate training and have the necessary knowledge to deliver skilled and efficient assistance whenever the Active Army calls on them to do so. In emergency situations, such as war or armed conflict, they can promptly provide highly-trained combat units and specialized technological support to the troops in need. Camorra reserves involved at a high level must have a thorough awareness of criminal mechanisms and mentality. Whereas in the army, officers acquire higher knowledge of their field thanks to specialized leadership training, in the Camorra, high-ranking women

\footnotetext{
22 "The Army, as one of the three military departments (Army, Navy and Air Force) reporting to the Department of Defence, is composed of two distinct and equally important components: the active component and the reserve components. The reserve components are the United States Army Reserve and the Army National Guard." (US Army 2013).
} 
typically come to gain expertise and criminal capability as a result of their prolonged proximity to Camorra actors and processes, and in consequence of this, consider illegality and violence as being normal aspects of life.

The USAR's contribution is not limited to offering support to the US active army in times of war; their help is also fundamental during peacetime, in case of catastrophic events. USAR officers are, in fact, also in charge of specific key functions of the whole army, such as planning, managing and implementing the training of all troops (reservists as well as active ones): "The Army Reserve's mission, under Title 10 of the U.S. Code, is to provide trained, equipped, and ready soldiers and cohesive units to meet the global requirements across the full spectrum of operations" (US Army Reserve 2013). Just like members of the US Army Reserve, women in the Camorra also provide a necessary and functional support to the criminal organisation during "normal" times: their behind-the-scenes activity provides essential assistance to men on an emotional, intellectual and professional level.

Although each individual member of the USAR is, to one extent or another, actively contributing to the accomplishment of the wider US Army's objectives, not every reservist may aspire to leadership roles in the ranks of the Army Reserve. Different positions in the military chain of command provide different opportunities to individuals. Within the ranks of USAR soldiers, for instance, there is a distinction between enlisted men and officers (US Army Reserve 2013). The former have a lower degree of authority than the latter and, even though undeniably essential to the successful implementation of missions, they will never be regarded as decision-makers or authorities. In fact, high-ranking officials are asked to master a deeper and more solid knowledge of the dynamics and processes of the military field, and they acquire such proficiency thanks to a special leadership training which provides them with the abovementioned grade of USAR officers (US Army Reserve 2013). ${ }^{23}$

The US Army Reserve is organized according to a particular hierarchy of power, and to become part of the command team certain special conditions need to be met. Not everyone can attain the status of officer in the army and, likewise, not all women involved in Camorra activities can reach important positions and roles in the hierarchy of the clan. The privileged status of certain women is guaranteed by their personal relationship with the clan's boss. They are sworn to secrecy, and are often the keepers of secret information. In fact, as pointed out, the few female leaders in the Neapolitan underworld that have emerged so far are always personally connected with the boss by intimate family bonds. Once placed in leadership roles, these women must demonstrate excellent criminal and leadership skills in order to manage the organisation and its activities efficiently, as they know all its secrets.

In short, women in the Camorra act as a real "reserve army;" they provide quintessential support and are an emergency resource for the clan, both in normal times and in periods of crisis. This approach stipulates that, as in the case of army reservists, Camorra women are (1) skilled, trained in everything (including violence, if necessary) and motivated; (2) they are constantly on standby, available and ready to make decisions and take action whenever the situation requires; (3) they have access to permanent training because they are in close proximity to a leader and skilled members; and, (4) they have access to special inside information and are sworn to secrecy.

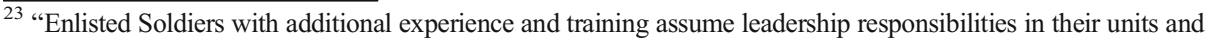
are recognized as Non-commissioned Officers (NCO). NCO ranks are corporal, sergeant, staff sergeant, sergeant first class, master sergeant, first sergeant, sergeant major and command sergeant major. Approximately $80 \%$ of Army Reserve Soldiers are Enlisted, and about half of those are NCOs. Officers are soldiers who have completed special leadership training." (USAR 2013).
} 
In all these brief case studies, the criteria of our definition of reserve army have been fulfilled: Rather than being a sign of the emanicipation of Neapolitan women in the Camorra, their role is that of "a reserve army," needed when clans are in crisis and later withdrawn.

\section{Conclusion}

The interpretation of the emerging leadership roles of women in the Camorra as a sign of structural transformation of the criminal system is, we believe, misleading because it assumes a deep, cultural shift towards gender parity on a broad, social level in Neapolitan civil society. In reality, this kind of change has not yet occurred, least of all in the most deprived sectors of Neapolitan society, from where most Camorra recruits come. Women are not "naturally" involved in decision-making in their clans. But rather, whether daughters, wives or lovers, they are enrolled into the clan's management and activities out of necessity during periods of crisis and a drought of possible male leaders; in other words, it is not a question of emanicipation but a problem of human resources for the clan.

For women who seek leadership positions, the only route to access the clan's power remains exclusively family ties, as Pizzini-Gambetta $(2009,270)$ makes clear: Would these "women have ever made it on their own? If we remove their male relatives would they keep their position?" Only the proximity to a camorrista, through marriage or kinship ties, can ensure them a privileged position for the leadership succession when the boss is absent. Being close relatives, wives, daughters, sisters, mothers or lovers to Camorra bosses, they have a high sense of loyalty and are devoted to the clan, not least because the criminal group normally coincides with the biological family.

The increased entrepreneurial scope of the Camorra, which aims at making profit by means of an extensive control of the territory, allows and requires the exploitation of skills and competencies other than violence. As the women in our case-studies have explained, women who gain power in Camorra clans often become the financial administrators of the clan, managing the common fund and the revenues of the clan and making decisions about member's wages and rewards. However, they do not do this in a vacuum but as a result of special training and in-depth inside knowledge.

Threats, punishments, killings and physical extortion of money are usually tasks left to men and foot soldiers, although the boss remains the one who has the very last word over all kinds of operations, generally manifesting a pitiless and often cruel personality. Despite this general trend in the Camorra, it is not possible to speak of a neat gender-based division of roles, for example, men dealing with violence while women focus on administrative and financial matters. In fact, the surprising ease with which female bosses are able to command merciless tortures and gruesome murderers demonstrates that resorting to violence is not a psychocultural taboo at all. Rather, the reason why Camorra women are less involved in violent situations is simply that first-hand use of violence by women is not necessarily something they are asked to prove, which differs from what happens with men. In fact, together with the status of capoclan that they inherit from the boss, they also inherit his "social capital," which provides them with an aura of authority that guarantees them the deference and respect of all clan members, as can be seen in the case of AM.

Thus, analysing Camorra women as being a "reserve army" excludes any possible feminist interpretation of their roles in terms of "female emancipation." The likelihood of a woman 
becoming the leader of a Camorra clan does not depend on how charismatic and competent she is, but rather on her origins and family relationships. Charsima helps, but if we remove the key male component from the equation, the career of a woman in the Camorra does not appear to have even a remote chance of taking off. This is confirmed by the facts: In the entire history of the Camorra there has never been one influential woman whose rise was not associated to family or sentimental connections with at least one prominent male figure of the clan. That is to say that a woman unrelated to a camorrista has never be permitted to reach the higher levels of the clan, and there is no evidence to suggest that this situation will change in the near future.

Women's active contribution to the Camorra is undeniable: they are the true "reserve army" of camorristi. A Camorra state witness made this clear when he argued:

Your wife, directly or indirectly, becomes involved in everything, so what happens when you end up in prison? Your members, spontaneously, it becomes a very natural thing, report to her, because they know very well, they are aware that she knows everything. And they also know very well that, somehow, you are in prison and are happier if they report to her rather than, for example, doing things without consulting anyone, even out of respect.

But, rather than speaking of "female emancipation" and gender parity, we prefer to use the concept of "exploitation" of available resources and skills in times of crisis, and we believe that these are more appropriate and useful to describe the status and role that women can acquire and play in the Camorra today. The methodology used in this study could in fact have wider application for the roles of women in parastatal organisations such as transnational organized crime groups, as well well as terrorist groups. To that extent, it could be considered an original contribution to the literature.

Open Access This article is distributed under the terms of the Creative Commons Attribution 4.0 International License (http://creativecommons.org/licenses/by/4.0/), which permits unrestricted use, distribution, and reproduction in any medium, provided you give appropriate credit to the original author(s) and the source, provide a link to the Creative Commons license, and indicate if changes were made.

\section{References}

Adler, F. 1975. Sisters in crime. New York: McGraw-Hill.

Allum, F. 2006. Camorristi, politicians, and businessmen: The transformation of organized crime in post-war Naples. Leeds: Northestern University Press.

Allum, F. 2007. Doing it for themselves or standing in for their men? Women in the Neapolitan camorra 19502003. In Women and the mafia: Female roles in organized crime structures, ed. G. Fiandaca, 9-17. New York: Springer.

Allum, F. 2016. The invisible camorra, Neapolitan crime families across Europe. Itaca: Cornell University Press.

Arsovska, J. 2015. Decoding Albanian organized crime: Culture, politics, and globalization. Berkeley: University of California Press.

Baxter, P., and S. Jack. 2008. Qualitative case study methodology: Study design and implementation for novice researchers. The Qualitative Report 13 (4): 544-559.

Beare, M. 2010. Women and organized crime. Report No. 013, 2010. Research and National Coordination, Organized Crime Division, Law Enforcement and Policy Branch, Public Safety Canada. http://publications. gc.ca/collections/collection_2012/sp-ps/PS4-106-2010-eng.pdf Accessed March 27, 2013.

Behan, T. 2002. See Naples and die. London: I. B. Tauris.

Block, A.A. 1980. East side, west side: organizing crime in New York, 1930-1950. Transaction publishers.

Brancaccio, L. 2017. I clan di camorra. Genesi e storia. Rome: Donzelli. 
Bruegel, I. 1979. Women as a reserve army of labour: A note on recent British experience. Feminist Review 3: $12-23$.

Campbell, A., S. Muncer, and D. Bibel. 2001. Women and crime. An evolutionary approach. Aggression and Violent. Behaviour 6: 481-497.

Crowe, S., K. Cresswell, A. Robertson, G. Huby, A. Avery, and A. Sheikh. 2011. The case study approach. $B M C$ Medical Research Methodology 11 (1): 11-100.

Di Fiore, G. 2008. L"impero dei Casalesi. Milano: Rizzoli.

Dino, A. 2007. Symbolic domination and active power: Female roles in criminal organisations. In 2007. Women and the Mafia: Female Roles in Organized Crime Structures, ed. G. Fiandaca. New York: Springer.

Direzione Nazionale Antimafia [DNA]. 2014. Relazione annuale sulle attività svolte dal Procuratore Nazionale Antimafia dalla Direzione Nazionale Antimafia nonché sulle dinamiche e strategie della criminalità organizzata di tipo mafioso nel periodo $1^{\circ}$ Iuglio 2012-30 Giugno 2013, January, Rome.

Fiandaca, G., 1997. La discriminante sessuale tra paradigmi giudiziali e paradigmi culturali. Segno. Vol. 13 (183).

Fiandaca, G., ed. 2007. Women and the mafia: Female roles in organized crime structures. New York: Springer.

Gribaudi, G., 2010. Donne di Camorra e identità di genere. In Meridiana, 2010. Donne di Mafia. Vol. 67: pp. 145-154. Rome: Viella SRL.

Gribaudi, G. \& Marmo, M., 2010. Che differenza fa. In Meridiana, 2010. Donne di Mafia. Vol. 67: pp. 9-20. Rome: Viella SRL.

Guardia di Finanza, 2005, Comunicazione di notizia di reato, ex art. 347 c.p.p., nei confronti di Caldarelli Raffaele + altri, Procedimento penale nr. 8536/06 R.G.N.R.. Napoli.

Hobbs, D., and G.A. Antonopoulos. 2014. How to research organised crime. In The Oxford handbook of organised crime, ed. L. Paoli, 96-117. New York: Oxford University Press.

Ingrascì, O. 2007. Donne d onore. Storie di mafia al femminile. Milano: Mondadori.

Longrigg, C. 1998. Mafia women. London: Vintage.

Madeo, L. 1997. Donne di Mafia. Milano: Baldini Castaldi.

Manna, A., 2005. La donna nel diritto penale. Indice Penale.

Marx, K. 1867. Das Kapital: kritik der politischen ökonomie. Germany: Verlag von Otto Meisner 1885: 1894.

Ministero dell"Interno (1996) Osservatorio Permanente sulla Criminalità, 1996, Rapporto Annuale sul Fenomeno della Criminalià organizzata per il 1995, "La Donne nella Criminalità Organizzata", Roma.

Perakyla, A. 1997. Reliability and validity in research based on tapes and transcripts In Silverman, D., ed. 1997. Qualitative research: Theory, method and practice. London: Sage.

Pine, J., 2012. The Art of Making Do in Naples, Minesota University Press.

Pizzini-Gambetta, V. 2008. Women and the mafia: A methodology minefield. Global Crime. Vol. 9 (4): 348-353. Pizzini-Gambetta, V. 2009. Women in Gomorrah. Global Crime 10 (3): 267-271.

Principato, T., and A. Dino. 1997. Mafia donna, le vestali del sacro e dell"onore. Palermo: Flaccovio Editore.

Rawlinson, P., 2000. Mafia, Methodology, and "Alien Culture", pp. 351-362. in Doing Research on Crime and Justice. New York: Oxford University Press.

Sales, I. 2006. Le strade della violenza. Naples: L”Ancora del Mediterraneo.

Savona, E., and G. Natoli. 2007. Women and other mafia type criminal organizations. In Women and the mafia: Female roles in organized crime structures, ed. G. Fiandaca. New York: Springer.

Seindal, R. 1998. Mafia and politics in Sicily, 1950-1997. Copenhagen: Museum Tusculanum Press.

Senato della Repubblica, 2015. Relazione sui Programmi di Protezione, sulla loro efficacia e sulle modalità generali di applicazione per coloro che collaborano con la giustizia, Roma.

Siebert, R. 1996. Secrets of life and death. Women and the mafia. London: Verso.

Siebert, R., 2007. Donne di mafia. Affermazione di un pseudo-soggetto femminile. Il caso della "ndrangheta in Fiandaca, G., ed., 2007. Women and the Mafia: Female Roles in Organized Crime Structures. New York: Springer.

Siebert, R., 2010. "Tendenze e prospettive” in Meridiana, Donne di Mafia. Vol. 67: pp. 21-33. Rome: Viella SRL.

Spradley, J.P. 2016. The ethnographic interview. Illinois: Waveland Press.

Tribunale di Napoli 2003, Sentenza contro Maria Licciardi + altri, Napoli.

Tribunale di Napoli 2007, Ufficio del Giudice per le indagini Preliminari, Sezione Quarta, Ordinanza Applicativa della Misura Cautelare Della Custodia in Carcere e Rigetto di Misura Cautelare nei confronti di Danese Ciro + 8, N R N R n. 29752/2007; Gip n. 25265/2008, OCC n. 737/2012, 26/12/12.

Tribunale di Napoli, 2011, Sentenza nei confronti di Maio Emilia + 1, RGPM n. 26137/10, n, 26740/10 RG GIP, $31 / 5 / 2011$.

Tribunale di Napoli 2016, Sezione GIP-GUP, Ufficio III, Ordinanza su Richiesta di Applicazione di Misure Cautelari nei confronti di AULITTO Ciro + 43, N. 15195/13 R. G., N. R. - D. D. A, N. 8564/14, R. G. G.I.P. -D. D. A, N/16 R. O. C. C. - D. D. A. 
US Army Reserve (USAR) website, 2013. The Army Reserve Mission [online]. Available at: http://www.usar. army.mil/ourstory/Pages/default.aspx [Accessed on $20^{\text {th }}$ June 2013].

US Army website (2013) The official homepage of the United States Army, 2013. Organization. [online]. Available at: http://www.army.mil/info/organization/ [Accessed on $20^{\text {th }}$ June 2013].

Zaccaria, A.M., 2010. L"emergenza rosa. Dati e suggestioni sulle donne di Camorra. In Meridiana, 2010. Donne di Mafia. Vol. 67: pp. 155-173. Rome: Viella SRL.

Zhang, S.X., K. Chin, and J. Miller. 2007. Women's participation in chinese transnational human smuggling: A gendered market perspective. Criminology 45 (3): 699-732.

Felia Allum is senior lecturer in the Department of Politics, Languages and International Studies at the University of Bath where she teaches and researches organized crime. Her lastest book "The Invisible Camorra" (Cornell University Press 2016) analyses the presence and role of the Neapolitan Camorra in Europe.

Irene Marchi has a mater's degree in International Relations \& European Politics from the University of Bath. She currently works in London in the field of Business Ethics \& Compliance. 